\title{
The Effect of Cause Related Marketing on Arua Phinisi Consumer Purchase Interest with Brand Image as Moderating Variable
}

\author{
Diah Ari Tapaningtyas \\ PT. Oase Bahtera Vakansi \\ d.tapaningtyas@gmail.com \\ https://doi.org/10.37715/rmbe.v1i2.2420
}

\begin{abstract}
This study aims to determine the influence of cause related marketing on Arua Phinisi's consumer purchase intention with brand image as a moderating variable. The number of respondents involved in this study are 55 respondents. All respondents are Arua Phinisi customers in 2020. Data in the study were obtained from the results of distributing questionnaires, which then analyzed using the Partial Least Square technique with the help of SmartPLS software. Based on the results of the analysis in this study, the following results were obtained: (1) cause related marketing has a positive and significant influence on purchase intention, the better the cause related marketing carried out by Arua Phinisi, the higher the consumer purchase intention; (4) brand image can moderate the influence of cause related marketing on Arua Phinisi's consumer purchase intention, a strong brand image will strengthen the influence of cause related marketing on consumer purchase intention.
\end{abstract}

\section{Keywords-Cause Related Marketing, Brand Image, Purchase Intention, Partial Least Square.}

\section{Introduction}

Indonesia as a maritime country has a coastline of $95,181 \mathrm{~km}$, the second longest in the world after Canada. Located in a tropical area with more than 17,508 islands, Indonesia has great potential in the tourism sector, especially marine tourism. Labuan Bajo is a gateway to tourist objects in the West Manggarai area, Flores, East Nusa Tenggara. The main attraction of the West Manggarai area is the Komodo National Park where there is a Komodo dragon (varanus komodoensis) reptile that only lives in Indonesia (Balai Taman Nasional Komodo (BTNK), 2014). Generally, tourists visiting Komodo National Park use liveaboard boats so they can also visit other islands in the West Manggarai area. The liveaboard concept is a ship made with living facilities such as a kitchen, dining room, bedroom, bathroom, and so on. Arua Phinisi is one of the liveaboard vessels operating in Labuan Bajo. Is a brand of PT. The Vakansi Ark Oasis, Arua Phinisi started operating in 2020. Arua Phinisi has a goal to take a share of the market and increase sales. According to Bigne et al. (2009), with the increasing competition in today's market, it is difficult for companies to differentiate their brands from competitors only by traditional attributes such as price or quality. Corporate social responsibility is one of the initiatives carried out by many companies to build a positive image, because it is considered capable of building the impression that the company cares about the interests of the community and is not only profit-oriented.

Cause related marketing can be defined as a marketing strategy that links fundraising for social issues with the purchase of products or services (Varadarajan \& Menon, 1988). Tsai (2009) states that cause related marketing has gained popularity among marketers who believe that this approach can increase both brand attitude and purchase intention. Gupta and Pirsch (2006) conducted research on the relationship between companies, social campaigns and consumers, and found that the match between the three groups will affect consumer responses, where there will be a positive attitude towards cooperation between companies and social campaigns carried out and will arise buying interest. product of the company. For the period October - December 2020, Arua Phinisi is collaborating with Taman Bacaan Pelangi which has been officially registered as the Rainbow Dream Nation Foundation. Arua Phinisi will donate 1 package of Illiteracy Free program worth IDR 1,500,000. Based on the background described above, this study aims to see whether the cause related marketing program carried out by Arua Phinisi has an effect on consumer buying interest, and whether Arua Phinisi's brand image can strengthen this influence. This research is expected to be used by Arua Phinisi as a consideration in making marketing and communication strategies. 


\section{Literature Review}

\subsection{Previous research}

Lin and Lin (2019) conducted a study to examine the effect of cause relate marketing on brand image and buying interest in the ecotourism industry. The results of this study are cause related marketing in the ecotourism industry should be combined with relevant products, and should provide special characteristics and themes to highlight the cause related marketing activities. Hannantyas et al. (2016) conducted a study to examine the role of cause-related marketing on the reputation of multinational companies, brand image, and buying interest. The case study was conducted on the Against Animal Testing campaign by The Body Shop company. From this research, it can be concluded that cause related marketing can provide great benefits to the company and cause, and significantly positive effect on the company's reputation, brand image, and buying interest. The conclusion of this study is: nonmonetary giving has advantages over monetary giving, monetary giving will be more effective if hedonic products are paired with low-fit causes, and when consumers perceive the company's motives as altruistic, consumers will give positive treatment to products and consumer buying interest becomes stronger.

\subsection{Theoretical basis}

\subsubsection{Cause related marketing}

Cause related marketing is a form of marketing communication and can be defined as a marketing program used to improve company performance and help social issues that are considered important, by linking fundraising for social programs carried out by non-profit organizations with the purchase of products or services. (Varadarajan \& Menon, 1988). According to Brink et al. (2006), there are four dimensions of Cause-related marketing, namely Congruency, Duration, Amount of resources invested (real object, money, service) and Senior management involvement.

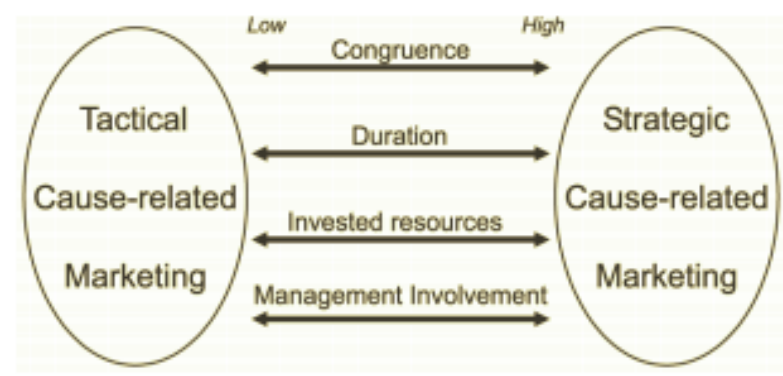

Figure 2.1 Schematic of cause related marketing characteristics

\subsubsection{Brand Image}

According to Kotler (2017), brand image can be defined as a set of beliefs, ideas, and impressions that consumers have of a brand. Through brand image, consumers can relate attributes and benefits to the brand and compare it with competitors (Keller \& Webster, 2004). Keller (1993) divides brand image into the following components::

1. Attributes: descriptive features that characterize a product, divided into two, namely product-related attributes (parts that must exist for the product to function) and non-product-related attributes external aspects of the product related to the use or purchase of the product.).

2. Benefits: benefits that consumers attribute to product attributes, categorized into functional benefits (benefits related to product-related attributes), symbolic benefits (related to non-product-related attributes), and experiential benefits (to what consumers feel such as satisfaction, experience)., stimulation, and so on).

3. Brand attitude: the overall assessment by consumers of the brand, from the aspect of its attributes and benefits.

\subsubsection{Buying Interest}

Kotler and Amstrong (2016) define buying interest as consumer behavior when receiving external stimulation and then based on personal characteristics carry out the decision-making process to make a purchase. According to Bearman et al. (2018), there are stages in the growth of buying interest, namely: stimulation, awareness, and information seeking. Furthermore, Kotler and Amstrong (2016) describe the stages of buying interest as follows:

1. Attention: the initial stage where the ad has an appeal with 3 aspects, namely the content of the message conveyed, the frequency of serving, and the visualization of the ad. 
2. Interest: the next stage where consumers are interested in the product or service introduced by the marketer. This is influenced by the effectiveness of the media used, consumer perceptions of the product, and the clarity of the message (Assael, 2002).

3. Desire: how advertising can drive consumers' desire to own the product. This is influenced by information about the superiority of the product, advertisements arouse the desire to have the product, and advertisements display reasons for owning the product.

4. Action: The final stage where consumers have the confidence to make a purchase.

Ferdinand (2006) identified buying interest with the following indicators:

a) Transactional interest, namely consumer interest to make a purchase.

b) Referential interest, namely consumer interest in recommending products.

c) Preferential interest, namely the interest of consumers who have a primary preference for certain products compared to other products.

\subsection{Relationship between variables}

d) Explorative interest, namely the interest of consumers to explore more information about a product.

The effect of cause related marketing on buying interest. Businesses that sell products with cause related marketing marketing strategies that match the identity of the masses can generate consumer buying interest (Lin \& Lin, 2019) and have a significant positive effect on buying interest (Hannantyas et al., 2016).

\section{Research Methods}

\subsection{Research Model}

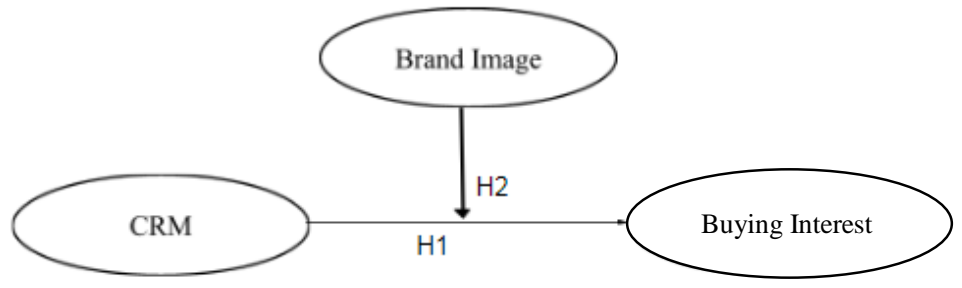

Figure 3.1 Research model

\subsection{Hypothesis}

Based on the research model, the hypotheses proposed by the researcher are:

H1: Cause related marketing has an influence on consumer buying interest in Arua Phinisi.

$\mathrm{H} 2$ : Brand image has a moderating role in the relationship between cause related marketing and consumer buying interest in Arua Phinisi.

\section{.3.3 Research Approach}

The researcher uses a quantitative approach in this study, namely the method used to answer a problem formulation made from a concept that generates a hypothesis (Sugiyono, 2017). The hypothesis will be tested using existing data, then tested statistically. Statistical test results are used to explain the hypothesis. The population of this research is all consumers of Arua Phinisi in 2020 as many as 55 people consisting of 7 foreigners and 48 Indonesian citizens. This study uses a total sampling technique, namely a sampling technique using the entire population as the research sample (Sugiyono, 2017). So the total sample is 55 respondents.

\subsection{Method of collecting data}

Sources of data for this study using primary data and secondary data. Primary data was collected using a questionnaire, while secondary data was obtained from literature studies in the form of theories and information from books, journals, and other sources related to this research. This questionnaire uses a Likert scale, using a score of 1 to 5 with the following details:

Table 3.1 Likert Scale for the questionnaire

\begin{tabular}{|l|l|}
\hline Mark & Explanation \\
\hline 1 & Strongly disagree \\
\hline 2 & Disagree \\
\hline 3 & Neutral \\
\hline 4 & agree \\
\hline 5 & Strongly agree \\
\hline
\end{tabular}


Online questionnaires were used in this study to speed up time and to obtain data from respondents who were outside the city of Surabaya.

\subsection{Variable Operation}

\subsubsection{Cause Related Marketing}

Cause related marketing indicators used in this study are:

a. Congruency (X1), namely the match between the company and the social program it supports.

b. Duration (X2), which is the length of time the company supports a social program.

c. Amount of resources invested (X3), namely contributions made to social programs.

d. Senior management involvement (X4), namely the level of top management involvement in supporting social programs.

\subsubsection{Brand image}

Brand indicator images consist of:

a. Attributes, Attributes can be divided into two, namely product-related attributes (M1) and non-productrelated attributes (M2).

b. Benefits, benefits can be categorized into functional benefits (M3), symbolic benefits (M4), and experiential benefits (M5).

c. Brand attitude (M6), namely the overall assessment by consumers of the brand, whether the product or service has certain attributes or benefits.

\subsubsection{Buying interest}

According to Ferdinand (2006), buying interest can be identified through the following indicators:

a. Transactional interest (Y1), namely consumer interest in making purchases.

b. Referential interest (Y2), namely consumer interest in recommending products.

c. Preferential interest (Y3), namely the interest of consumers who have a preference for certain products.

d. Explorative interest (Y4), namely consumer interest to gather more information related to the product.

\subsection{Analysis Method}

This study uses descriptive analysis and analysis of Structural Equation Modeling (SEM) with SmartPLS 3.0 software. In this study, descriptive analysis will be used to analyze the characteristics of Arua Phinisi consumers. SEM is a multivariate statistical analysis technique used in testing direct and indirect effects, either unidirectional or not, so as to produce a comprehensive picture of the research model (Sugiyono, 2017).

\subsection{Validity and Reliability Test}

\subsubsection{Outer model}

Ghozali (2014) describes the outer model as a measurement model that specifies the relationship between indicators and their constructs. The outer model testing steps are as follows:

1. Convergent validity. To test convergent validity, the outer loading value is used. The indicator is considered valid if it has an outer loading value $>0.7$.

2. Discriminant Validity. Discriminant validity is carried out to ensure that the concept of each variable is different from other variables. The model is said to have good discriminant validity if the AVE square value of each exogenous variable (the value on the diagonal) exceeds the value of the relationship between the variable and other variables (the value below the diagonal).

3. Composite Reliability. Composite reliability is used in testing the reliability values of the indicators for each variable. Reliability test with composite reliability using Cronbach's Alpha value. The variable is declared reliable if the value of Cronbach's Alpha > 0.7 .

\subsubsection{Inner model}

To test the relationship between variables, testing is carried out on the inner model, with the following steps:

1. Goodness of fit model. The value of Standardized Root Mean Square Residual (SRMR) is used to see the fit of the PLS model. The PLS model is declared to meet the goodness of fit model criteria if the SRMR value $<0.10$ and declared perfect fit if the value of SRMR $<0.08$.

2. Test the direct effect. The independent variable is said to have a significant effect on the dependent variable if it has a $P$ value $<0.05$ and $t$ count $>1.65$.

3. Coefficient of Determination. In PLS analysis, the coefficient of determination is seen from the value of $\mathrm{R}$ Square with a value between $0-1$. The analysis model in this study is said to be getting better if $\mathrm{R}^{2}$ is getting closer to number 1 . 


\section{$4 \quad$ Results and Discussion}

The object of research in this research is Arua Phinisi, a brand of PT Oase Bahtera Vakansi, a company engaged in tourism. Arua Phinisi offers tour package products by phinisi boat in Labuan Bajo for one to four days, visiting tourist objects in the West Manggarai area, West Nusa Tenggara, such as Komodo National Park, Padar Island, Pink Beach, Manta Point, and others. Questionnaires were distributed in January 2021 to 55 respondents in the form of online questionnaires. Respondent descriptions are used to classify the respondent's character which includes gender, age and nationality with the following results.

Based on these results, it can be seen that the percentage of gender is relatively balanced, with the percentage of men at $47.27 \%$ and women at $52.72 \%$. This shows that Arua Phinisi is favored by both men and women, and there is no tendency to either gender. The dominating age group is the $25-39$ year age group at $45.45 \%$ followed by the 40-59 year age group at $32.73 \%$. This can reflect that this type of tour package is favored by the productive age group and can also reflect the financial capabilities of consumers where those aged 25 years and over generally already have a steady income and are able to spend a minimum of IDR 5,000,000 for vacation needs. The percentage of Indonesian citizens is very large, namely $87.27 \%$ due to restrictions on entry to Indonesia due to the Covid-19 pandemic.

\subsection{Variable Descriptive Analysis}

\subsubsection{Cause related marketing variable $(X)$}

Table 4.1. The mean and standard deviation of cause related marketing variables

\begin{tabular}{|l|l|c|c|}
\hline \multicolumn{1}{|c|}{ Variable } & \multicolumn{1}{|c|}{ Statement } & \multicolumn{1}{|c|}{$\begin{array}{c}\text { Standard } \\
\text { Deviation }\end{array}$} \\
\hline $\begin{array}{l}\text { Cause Related } \\
\text { Marketing }\end{array}$ & $\begin{array}{l}\text { I like it better if Arua Phinisi establishes partnership with non-profit organizations that focus on } \\
\text { issues related to Arua Phinisi's business (example: marine-life conservation, beach pollution, etc) } \\
\text { rather than unrelated issues (example: children's welfare, women's right, etc). (X1) }\end{array}$ & 3,6727 & 1,1107 \\
\cline { 2 - 4 } & $\begin{array}{l}\text { When it comes to the duration of the partnership, I like it better if Arua Phinisi commits to a } \\
\text { longer period (example: partnering with 1 organization for 1 year), rather than a shorter period } \\
\text { (example: changing organization every 3 months). (X2) }\end{array}$ & 3,9636 & 1,0357 \\
\cline { 2 - 5 } & When it comes to the portion of the profit donated, the higher the better. (X3) & 2,9273 & 0,9786 \\
\cline { 2 - 5 } & I like it better if Arua Phinisi's top management (owners/directors) are actively involded. (X4) & 4,0546 & 0,7798 \\
\hline
\end{tabular}

\section{Sumber: processed data (2021)}

Table 4.1. shows the highest mean value is found in the X4 indicator with the statement "I like it better if Arua Phinisi's top management (owners/ directors) are actively involved" which is 4.0546 . This indicates that this is the most significant cause-related marketing indicator in this study. The X3 indicator with the statement "When it comes to the portion of the profit donated, the higher the better" has the lowest mean of 2.9273 and is very far from the mean of other indicators. It can be concluded that consumers do not care how large the amount of donations given by Arua Phinisi in doing cause related marketing.

\subsubsection{Brand image variable $(M)$}

Table 4.2 The mean and standard deviation of the brand image variable

\begin{tabular}{|c|c|c|c|}
\hline Variabel & Statement & Mean & $\begin{array}{l}\text { Standard } \\
\text { Deviation }\end{array}$ \\
\hline \multirow{6}{*}{$\begin{array}{l}\text { Brand } \\
\text { Image }\end{array}$} & Arua Phinisi's boat and facilities are excellent. (M1) & 4,4 & 0,5644 \\
\hline & Arua Phinisi offers high level of service. (M2) & 4,5819 & 0,5674 \\
\hline & Traveling with Arua Phinisi is as good as my expectation. (M3) & 4,5273 & 0,5727 \\
\hline & $\begin{array}{l}\text { Traveling with Arua Phinisi gives me positive emotions (example: joy, happiness, etc). } \\
\text { (M4) }\end{array}$ & 4,7091 & 0,5331 \\
\hline & Traveling with Arua Phinisi gives me prestige. (M5) & 4,1273 & 0,7215 \\
\hline & Overall, I have a positive attitude toward Arua Phinisi. (M6) & 4,7091 & 0,4584 \\
\hline
\end{tabular}

Source: processed data (2021)

Table 4.2. shows the mean values of all indicators of brand image variables tend to be high, this illustrates that most consumers consider that Arua Phinisi already has a good brand image. Indicators M4 with the statement "traveling with Arua Phinisi gives me positive emotions (example: joy, happiness, etc)" and M6 with the statement "overall, I have a positive attitude toward Arua Phinisi" have the highest mean values of 4.7091 each. Meanwhile, the statement with the lowest standard deviation is the M6 statement. So it can be said that the M6 indicator is the most significant indicator for the brand image variable in this study. It can be concluded that although when traveling 
with Arua Phinisi consumers feel disappointed about things that are not in line with expectations, but overall consumers are satisfied and have a positive attitude towards Arua Phinisi.

The M5 indicator with the statement "traveling with Arua Phinisi gives me Prestige" is the indicator with the lowest mean of 4.1273. This is understandable because the Arua Phinisi ship is not a luxury ship aimed at the upper class.

\subsubsection{Purchase interest variable $(Y)$}

Table 4.3 Value mean and standard deviation in the variable buying interest

\begin{tabular}{|l|l|l|l|l|}
\hline Variable & \multicolumn{1}{|c|}{ Statement } & Mean & $\begin{array}{l}\text { Standard } \\
\text { Deviation }\end{array}$ & \multicolumn{1}{|c|}{ Category } \\
\hline \multirow{2}{*}{$\begin{array}{l}\text { Interest } \\
\text { Intering }\end{array}$} & I have the intention to book a trip with Arua Phinisi in the future. (Y2) & 4.091 & 0.8876 & High \\
\cline { 2 - 6 } & I am willing to recommend Arua Phinisi to others. (Y2) & 4.8364 & 0.3734 & High \\
\cline { 2 - 6 } & I would prefer Arua Phinisi rather than any other boats available. (Y3) & 4.0545 & 0.8696 & High \\
\cline { 2 - 6 } & $\begin{array}{l}\text { I am interested to know about Arua Phinisi's programs, updates, and other } \\
\text { informations. (Y4) }\end{array}$ & 4.1455 & 0.8481 & High \\
\hline
\end{tabular}

Source: processed data (2021)

Table 4.3. shows that the Y2 indicator with the statement "I am willing to recommend Arua Phinisi to others " has the highest mean value of 4.8364 and the lowest standard deviation of 0.3734 . This shows that the Y2 indicator is the strongest buying interest indicator in this study. The value of $\mathrm{Y} 2$ when compared to other indicators is very high and almost touches the highest value, which is 5. Given that the respondents are Arua Phinisi consumers who have traveled with Arua Phinisi, it can be concluded that the possibility of repurchase is not high, and consumers are assumed to want to try other ships in future. Nevertheless, consumers are very willing to recommend Arua Phinisi to others

\subsection{Validity and Reliability Test}

Based on the design hypothesis proposed in this study, the scheme of the PLS model is as follows:

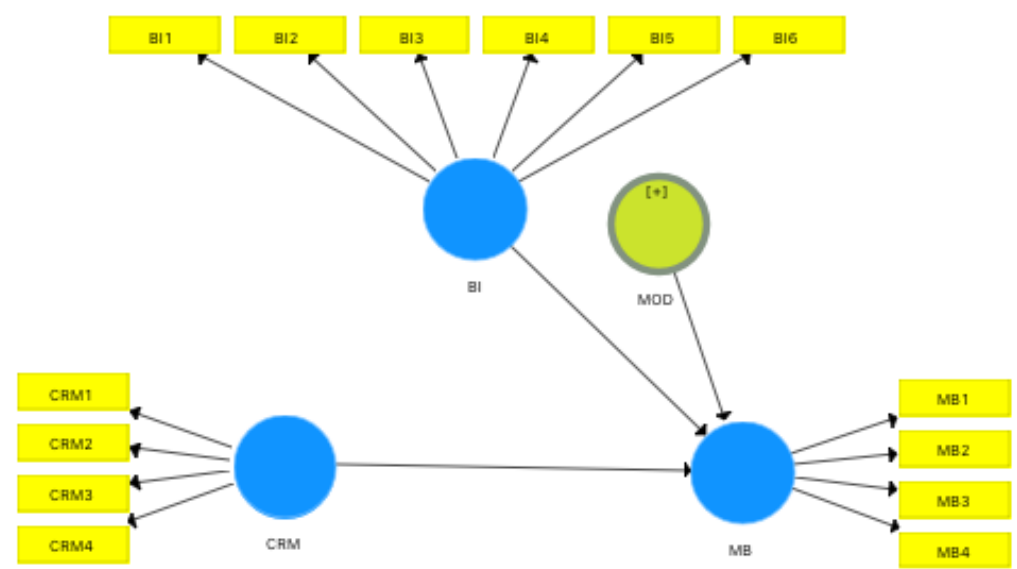

Figure 4.1 Scheme model PLS

\subsubsection{Outer model test}

1. Convergent validity

To test convergent validity, the loading factor value is used for each indicator. The indicator is declared valid if it has a loading factor value of $>0.7$. The following are the results of the validity test on the cause related marketing research variables, brand image, and buying interest as well as the indicators.

Table 4.4. Result of Validity Test

\begin{tabular}{|c|c|c|c|c|c|c|c|}
\hline \multirow[b]{2}{*}{ Variable } & \multirow[b]{2}{*}{ Indicator } & \multicolumn{6}{|c|}{ Convergent Validity } \\
\hline & & $\begin{array}{c}\text { Loading } \\
\text { Factor }\end{array}$ & $\begin{array}{c}\text { Mark } \\
\text { Criteria }\end{array}$ & Conclusion & AVE & Criteria Value & Conclusion \\
\hline \multirow[t]{4}{*}{ Cause Related Marketing } & $\mathrm{X} 1$ & 0,913 & 0,7 & Valid & \multirow[t]{4}{*}{0,877} & \multirow[t]{4}{*}{0,5} & \multirow[t]{4}{*}{ Valid } \\
\hline & $\mathrm{X} 2$ & 0,926 & 0,7 & Valid & & & \\
\hline & $\mathrm{X} 3$ & 0,963 & 0,7 & Valid & & & \\
\hline & $\mathrm{X} 4$ & 0,942 & 0,7 & Valid & & & \\
\hline Brand Image & M1 & 0,949 & 0,7 & Valid & 0,871 & 0,5 & Valid \\
\hline
\end{tabular}




\begin{tabular}{|c|c|c|c|c|c|c|c|}
\hline & M2 & 0,884 & 0,7 & Valid & & & \\
\hline & M3 & 0,961 & 0,7 & Valid & & & \\
\hline & M4 & 0,959 & 0,7 & Valid & & & \\
\hline & M5 & 0,919 & 0,7 & Valid & & & \\
\hline & M6 & 0,925 & 0,7 & Valid & & & \\
\hline \multirow[t]{3}{*}{ Buying Interest } & Y1 & 0,945 & 0,7 & Valid & \multirow[t]{3}{*}{0,877} & \multirow[t]{3}{*}{0,5} & \multirow[t]{3}{*}{ Valid } \\
\hline & Y2 & 0,956 & 0,7 & Valid & & & \\
\hline & Y3 & 0,943 & 0,7 & Valid & & & \\
\hline Moderation & & 1,082 & 0,7 & Valid & 1,000 & 0,5 & Valid \\
\hline
\end{tabular}

Source: processed data (2021)

Table 4.4. shows that all loading factor values $>0.7$ so it can be stated that all indicators are valid. In addition to looking at the loading factor value, convergent validity must also be assessed from the AVE value of each variable. The value of the AVE criteria $>0.5$ is declared valid. Table 4.4. shows that all AVE values $>0.5$ so it can be said that all variables are valid.

2. Discriminant validity.

The model is said to have good discriminant validity if the AVE squared value of each variable (the value on the diagonal line) exceeds the correlation value between that variable and other variables (the value below the diagonal line). The discriminant validity test got the following results;

Table 4.5. Discriminant validity test results for the Fornell Larcker method

\begin{tabular}{|l|l|l|l|l|}
\hline $\begin{array}{l}\text { Variabel } \\
\text { BI }\end{array}$ & $\begin{array}{l}\text { BI } \\
0.933\end{array}$ & CRM & MB & MODERATION \\
\hline CRM & 0.368 & 0.936 & & \\
\hline MB & 0.617 & 0.454 & 0.936 & \\
\hline MODERATION & -0.619 & -0.581 & -0.224 & 1.000 \\
\hline \multicolumn{5}{|c|}{ Sumber: processed data (2021) }
\end{tabular}

The results of the discriminant validity test in the table above show that:

a. The brand image (BI) variable has an AVE square root value of 0.933. This value is higher than the correlation value of brand image to other variables ( 0.368 to cause related marketing (CRM), 0.617 to buying interest (MB) and -0.619 to Moderation). Based on this data, it can be concluded that the BI variable meets the required discriminant validity criteria.

b. The CRM variable has an AVE square root value of 0.936 . This value is higher when compared to the correlation value of CRM with other variables $(0.454$ to $\mathrm{MB}, 0.368$ to $\mathrm{BI}$ and -0.581 to Moderation) so it can be concluded that the CRM variable meets the required discriminant validity criteria.

c. The MB variable has an AVE square root value of 0.936. This value is higher than the correlation value of buying interest with other variables ( 0.454 to CRM, 0.617 to $\mathrm{BI}$ and -0.224 to Moderation) so it can be concluded that the MB variable has met the required discriminant validity criteria.

d. The moderating variable has an AVE square root of 1,000. This value is higher than the moderating correlation value with other constructs $(-0.581$ for CRM, -0.224 for $\mathrm{MB}$ and -0.619 for $\mathrm{BI})$ so it can be concluded that the moderating variable has met the required discriminant validity criteria.

Based on the description above, the authors conclude that all variables in the PLS model have good discriminant validity. In addition to using the Fornell Larcker method, discriminant validity can also be seen from the cross loading value of each indicator on the construct. The indicator is declared to meet the discriminant validity criteria if the cross loading indicator on the construct has a higher value than the cross loading indicator value against other constructs. The cross loading value can be seen in the following table.

Table 4.6. Value of cross loading indicator

\begin{tabular}{|l|l|l|l|l|}
\hline & BI & CRM & MB & MODERATION \\
\hline BI1 & 0.949 & 0.312 & 0.545 & -0.578 \\
\hline BI2 & 0.884 & 0.404 & 0.561 & -0.592 \\
\hline BI3 & 0.962 & 0.322 & 0.638 & -0.574 \\
\hline BI4 & 0.959 & 0.405 & 0.629 & -0.589 \\
\hline
\end{tabular}




\begin{tabular}{|l|l|l|l|l|}
\hline BI5 & 0.919 & 0.264 & 0.557 & -0.563 \\
\hline BI6 & 0.925 & 0.349 & 0.506 & -0.566 \\
\hline CRM * BI & -0.618 & -0.582 & -0.224 & 1.000 \\
\hline CRM1 & 0.320 & 0.913 & 0.361 & -0.486 \\
\hline CRM2 & 0.381 & 0.926 & 0.399 & -0.583 \\
\hline CRM3 & 0.314 & 0.964 & 0.366 & -0.514 \\
\hline CRM4 & 0.354 & 0.942 & 0.529 & -0.575 \\
\hline MB1 & 0.515 & 0.456 & 0.945 & -0.145 \\
\hline MB2 & 0.668 & 0.469 & 0.956 & -0.290 \\
\hline MB3 & 0.598 & 0.410 & 0.943 & -0.188 \\
\hline MB4 & 0.508 & 0.354 & 0.901 & -0.202 \\
\hline \multicolumn{5}{|l|}{ Source: processed data (2021) }
\end{tabular}

Table 4.6. shows the cross loading indicator value BI1 - BI6 has the highest value on the brand image variable, not on the buying interest variable, cause related marketing or moderating constructs. This shows that the BI1-BI6 indicators can measure the brand image variable validly. Likewise for other variables, all indicators have measured the construct well so that discriminant validity based on the cross loading value is met.

3. Composite reliability

The reliability test was carried out using composite reliability and Cronbach's Alpha values. The following are the results of the reliability test on the cause related marketing variables, brand image, and buying interest.

Table 4.7 Reliability test results

\begin{tabular}{|l|l|l|l|l|l|l|}
\hline \multirow{2}{*}{ Variable } & \multicolumn{4}{l|}{ Composite Reliability } & \multicolumn{2}{l|}{ Cronbach's Alpha } \\
\cline { 2 - 7 } & Value & Criteria value & Conclusion & Value & Criteria value & Conclusion \\
\hline Cause related marketing & 0.966 & 0.7 & Reliable & 0.954 & 0.7 & Reliable \\
\hline Brand image & 0.976 & 0.7 & Reliable & 0.970 & 0.7 & Reliable \\
\hline Buying interest & 0.966 & 0.7 & Reliable & 0.953 & 0.7 & Reliable \\
\hline Moderation & 1,000 & 0.7 & Reliable & 1,000 & 0.7 & Reliable \\
\hline
\end{tabular}

Table 4.7 shows that all variables have a composite reliability value $>0.7$ and a value of Cronbach's Alpha $>0.7$ so that all variables can be declared reliable.

\subsubsection{Inner Model Test}

1. Direct influence testing

Table 4.8. Goodness of fit model

\begin{tabular}{|c|c|c|}
\hline & Saturated Model & Estimated Model \\
\hline SRMR & 0.061 & 0.064 \\
\hline \multicolumn{3}{|c|}{ Source: processed data (2021) }
\end{tabular}

The test results show that the SRMR value is 0.061 . Because the SRMR value is $<0.08$, the PLS model in this study can be declared perfect fit and is suitable to be used to test the research hypothesis.

2. Direct influence testing.

In the SmartPLS program, the influence between variables can be seen by bootstrapping. The path is declared positive and significant if the $\mathrm{P}$ value $<0.05$, the value of $\mathrm{T}$ statistics $>1.65$ and the path coefficient is positive. The model generated by the bootstrapping process can be seen in the following figure: 


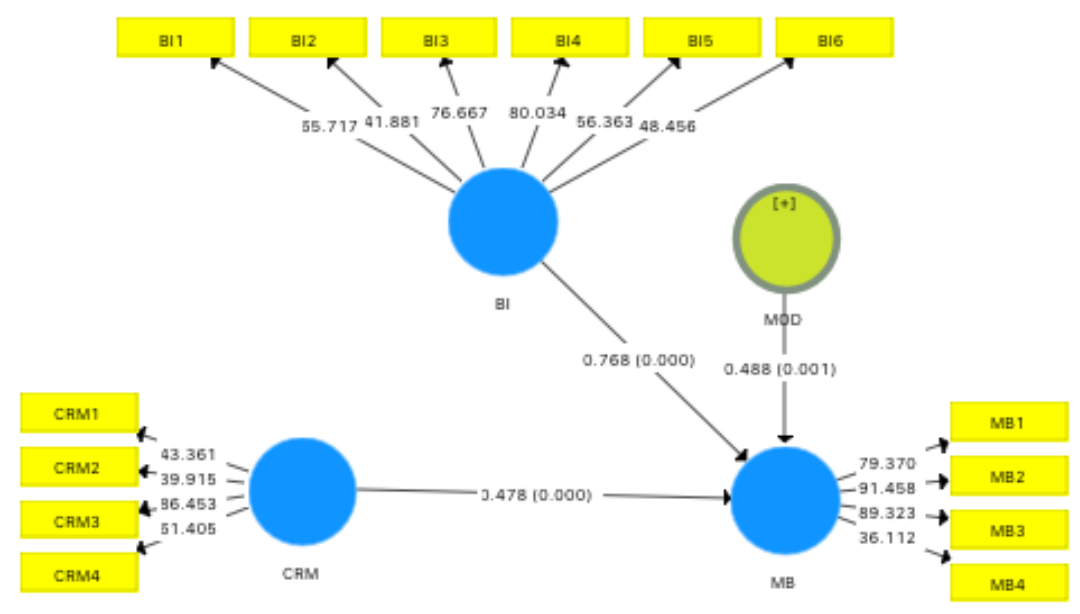

Figure 4.2 The estimation results of the PLS bootstrapping model

Figure 4.2 shows that all paths have a $\mathrm{P}$ value $<0.05$ so that it can be said to be significant. Further details can be seen in the following table:

Table 4.9. Partial effect test results

\begin{tabular}{|l|c|c|c|c|r|}
\hline & $\begin{array}{c}\text { Original Sample } \\
(\mathbf{O})\end{array}$ & $\begin{array}{c}\text { Sample Mean } \\
(\mathbf{M})\end{array}$ & $\begin{array}{c}\text { Standard Deviation } \\
(\text { STDEV })\end{array}$ & $\begin{array}{c}\text { T Statistics } \\
(\mid \mathbf{O} / \text { STDEV })\end{array}$ & P Values \\
\hline BI -> MB & 0.768 & 0.769 & 0.114 & 6.704 & $\mathbf{0 . 0 0 0}$ \\
\hline CRM -> MB & 0.478 & 0.480 & 0.117 & 4.073 & $\mathbf{0 . 0 0 0}$ \\
\hline MOD -> MB & 0.488 & 0.496 & 0.144 & 3.387 & $\mathbf{0 . 0 0 2}$ \\
\hline
\end{tabular}

Table 4.9. shows that all paths have a $\mathrm{P}$ value $<0.05$ and a $\mathrm{T}$ statistics value $<1.65$ so it can be stated that all paths are significant. Further explanations for each path are as follows:

a) Brand image path buying interest

On the track that shows the brand image of the buying interest (BI $\square \mathrm{MB}$ ), the $\mathrm{P}$ value is 0000 , the value of $\mathrm{T}$ statistic is 6,704 and is positive path coefficient of 0.768 . The three conditions are met so that it can be concluded that brand image has a positive and significant effect on buying interest.

b) Cause related marketing path interested in buying

On the track show cause related marketing towards buying interest (CRM $\square \mathrm{MB}$ ), the $\mathrm{P}$ value is 0000 , the value of $\mathrm{T}$ statistic is 4,073 and the path coefficient is positive for 0478 . The three conditions are met so that it can be concluded that cause related marketing has a positive and significant effect on buying interest.

c) Moderation path buying interest

On the track that shows the moderating effects of brand image on cause related marketing influences on buying interest (MOD $\square \mathrm{MB}$ ), the $\mathrm{P}$ value is 0000 , the value of $\mathrm{T}$ statistic is 3,387 and the path coefficient is positive for 0488 . The three conditions are met so that it can be concluded that brand image can strengthen the influence of cause related marketing on buying interest.

3. Coefficient of determination

The coefficient of determination is seen from the value of $\mathrm{R}$ Square with a value between $0-1$. The higher the value of $\mathrm{R}$ Square, the higher the influence of the independent variable on the dependent variable. Here are the results of the PLS.

Table 4.10. Coefficient of determination

\begin{tabular}{|l|c|c|}
\hline Variable & R Square & R Square Adjusted \\
\hline Buying interest & 0.572 & 0.547 \\
\hline \multicolumn{3}{|c|}{ Source: data processed 2021 }
\end{tabular}

Table 4.10. shows the value of $\mathrm{R}^{2}$ adjusted for variables buying interest for 0547 which means that the cause related marketing has an effect on buying interest at 54.7\% while the remaining $45.3 \%$ influenced by other factors outside of cause related marketing. 


\subsubsection{Hypothesis testing}

The research hypotheses were tested based on the results of the PLS analysis. The following is a summary of the results of the PLS analysis that has been carried out.

Table 4.11. Summary of hypothesis testing results

\begin{tabular}{|l|l|l|l|}
\hline Hypothesis & T Statistics & P Values & Conclusion \\
\hline (1) Cause related marketing affects buying interest & 4.073 & 0.000 & Accepted \\
\hline (2) Brand image can moderate the effect of cause related marketing on buying interest & 3.387 & 0.001 & Accepted \\
\hline
\end{tabular}

Sumber: data processed (2021)

From Table 4.11. the test results can be described as follows:

1. Hypothesis 1

Hypothesis 1 states that cause related marketing has an effect on buying interest. The research analysis got the result that the $\mathrm{P}$ value was 0.000 and the T statistic was 4.073. Because the value of the path $\mathrm{P}$ value $<0.05$ and and the value of $\mathrm{T}$ statistic $>1.65$, it can be concluded that cause related marketing has a positive and significant effect on buying interest. The better cause related marketing is done, the consumer's buying interest will increase. This description supports hypothesis 1 and it is stated that hypothesis 1 is accepted.

2. Hypothesis 2

Hypothesis 2 states that brand image can moderate the effect of cause related marketing on buying interest. The research analysis got the result that the $\mathrm{P}$ value was 0.001 and the $\mathrm{T}$ statistic was 3.387 . Because value $\mathrm{P}$ value path $<0.05$ and and the value of $\mathrm{T}$ statistic $>1.65$, it can be concluded that brand image can moderate the effect of cause related marketing on buying interest, and can strengthen the influence of cause related marketing on buying interest. This description supports hypothesis 2 and it is stated that hypothesis 2 is accepted.

\section{$5 \quad$ Conclusions and Practical Implication}

\subsection{Conclusion}

Based on the discussion in chapter 5, the author can draw the conclusion that Cause related marketing has a positive and significant effect on buying interest. This shows that cause related marketing is a factor that influences the level of buying interest in Arua Phinisi. The better cause related marketing is carried out, the higher the buying interest of Arua Phinisi consumers. In addition, brand image can moderate the effect of cause related marketing on buying interest. This shows that brand image has a role in the relationship between cause related marketing and purchase intention. A good brand image will strengthen the influence of cause related marketing on buying interest.

Suggestions for Arua Phinisi to be able to formulate in depth the image to be obtained and the intended target market, so as to be able to design an effective marketing strategy. If you want to continue the cause related marketing strategy, it is advisable to work with organizations that are compatible with Arua Phinisi's target market products, and communicate to consumers with languages and communication media that are suitable for Arua Phinisi's target market.

\subsection{Managerial implications}

The percentage of respondents' gender is relatively balanced and shows that Arua Phinisi is favored by both men and women. Arua Phinisi may use this data in its marketing communications, using language and themes that are neutral and do not tend to just one gender. The largest age group is the productive age group aged 25-59. This data can be used by Arua Phinisi to design tour packages with activities that are suitable and favored by this age group. This age group is generally already married, so Arua Phinisi must ensure that the Arua Phinisi ship is safe for carrying small children and also prepare additional facilities such as children's buoys, swimming tires, children's frog legs, and so on. This age group is also suitable to be offered a honeymoon package. Although the percentage of foreign tourists is small due to the Covid-19 pandemic, Arua Phinisi should be prepared to serve a western food menu or a vegetarian menu to anticipate guest requests.

Cooperation carried out in the future should be carried out with organizations that have social programs that are still related to Arua Phinisi products, such as marine conservation programs, programs to clean up trash on beaches, and so on. Questionnaire statements that measure symbolic benefits have a very high mean. Arua Phinisi can use this in promoting products, by emphasizing the symbolic benefits that consumers will get, such as a unique 
experience, the sensation of sailing on a Phinisi ship, and so on. Arua Phinisi can take advantage of this opportunity to ask for testimonials from consumers to be displayed on the website or social media Arua Phinisi. Arua Phinisi can also ask consumers to make reviews on the internet such as Tripadvisor, Google Reviews, and etc.

\section{References}

Assael, H. (2002). Consumer behavior and marketing action (4th ed.). Boston: PWS-Kent Publishing Company.

Balai Taman Nasional Komodo (BTNK). (2014). Rencana strategis balai Taman Nasional Komodo 2014-2019. Labuan Bajo: Balai Taman Nasional Komodo.

Berman, B., Evans, J. R., \& Chatterjee, P. (2018). Retail management: a strategic approach. Pearson Education Limited.

Bigné-Alcañiz, E., Currás-Pérez, R., \& Sánchez-García, I. (2009). Brand credibility in cause-related marketing: The moderating role of consumer values. Journal of Product \& Brand Management, 18(6), 437-447. https://doi.org/10.1108/10610420910989758

Ferdinand, A. (2006). Metode penelitian manajemen (Edisi kedua). Semarang: Badan Penerbit UNDIP.

Ghozali, I. (2014). Structural equation modeling metode alternatif dengan partial least square (PLS) dilengkapi Software SmartPLS 3.00 Xistat 2014 dan WarpPLS 4.0 (4th ed.). Semarang: Badan Penerbit Universitas Diponegoro Semarang.

Gupta, S., \& Pirsch, J. (2006). The company-cause-customer fit decision in cause-related marketing. Journal of Consumer Marketing, 23(6), 314-326. https://doi.org/10.1108/07363760610701850

Hannantyas, A. A., Yulianto, E., \& Mawardi, M. K. (2016). The role of cause-related marketing on multinational corporate reputation, brand image, and purchase intention in Indonesia and Thailand (Study case on The Body Shop against animal testing campaign). Jurnal Administrasi Bisnis, 33(2), 11-17.

Keller, K. L. (1993). Conceptualizing, measuring, and managing customer-based brand equity. Journal of Marketing, 57(1), 1-22.

Keller, K. L., \& Webster, F. (2004). A roadmap for branding industrial markets. SSRN Electronic Journal, 11(5), 388-402. https://doi.org/10.2139/ssrn.530823

Kotler, P., \& Amstrong, G. (2016). Principles of marketing (16th ed.). New Jersey : Pearson Prentince Hall.

Lin, S.-C., \& Lin, M. T.-Y. (2019). A study of the effects of cause-related marketing on brand image and purchase intention in ecotourism. Ekoloji, 28(107), 2887-2892.

Sugiyono, S. (2017). Metode penelitian kuantitatif, kualitatif, dan R\&D. Bandung: Alfabeta.

Tsai, S.-P. (2009). Modeling strategic management for cause-related marketing. Marketing Intelligence \& Planning, 27(5), 649-665. https://doi.org/10.1108/02634500910977872

van den Brink, D., Odekerken-Schröder, G., \& Pauwels, P. (2006). The effect of strategic and tactical cause-related marketing on consumers' brand loyalty. Journal of Consumer Marketing, 23(1), 15-25. https://doi.org/10.1108/07363760610641127

Varadarajan, P. R., \& Menon, A. (1988). Cause-related marketing: A coalignment of marketing strategy and corporate philanthropy. Journal of Marketing, 52(3), 58. https://doi.org/10.2307/1251450 